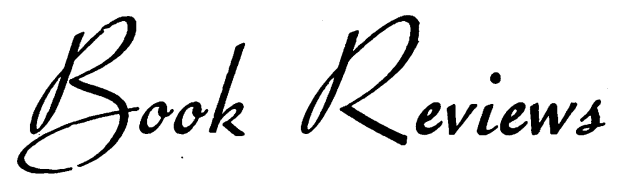

\section{OUTLINE OF FRACTURES, INCLUDING JOINT INJURIES}

By John Crawford Adams, M.D., F.R.C.S. Pp. vii +248 , with 218 illustrations. Edinburgh: E. \& S. Livingstone Ltd. I957. 27s. 6d.

The detailed management of bone and joint injuries is of concern only to the specialist working in the fracture clinics, where such injuries are nowadays usually treated. The general practitioner, medical student and physiotherapist need to know only the principles on which treatment is based, the methods of diagnosis and something of the complications that may arise. It is with these requirements in mind that Mr. Adams has written this companion volume to his ' Outline of Orthopaedics.' With economical prose and a generous number of illustrations, diagrams and summaries he has compressed into a small volume the essentials of modern practice.

A short historical introduction points out how relatively recent is the rational and organized treatment of fractures. Two general chapters follow, after which the injuries of the trunk and limbs are described systematically.

With the concentration of fracture treatment in special centres operative treatment has become increasingly safe. Mr. Adams points out clearly the situations where surgery is advantageous. $\mathrm{He}$ is particularly helpful in discussing ankle fractures, for which he has an agreeably simple classification. The necessity for screw fixation in fractures of the medial malleolus and inferior tibio-fibular diastasis is emphasized. On the troublesome subject of crush fractures of the calcaneum attempts at operative reduction are deprecated in favour of treatment by non-weight-bearing exercises.

A clear and reasoned account is given of spinal injuries. In the management of paraplegics Holdsworth's methods are followed. An innovation is made in the nomenclature of injuries of the hip; trochanteric fractures are not included under the title of fracture of the neck of the femur. This is very reasonable in view of the vastly different prognosis of the two injuries, but may occasionally lead to some confusion among those used to the older description of two types of femoral neck fracture, extracapsular and intracapsular.

Excision of the patella in young adults is advised against unless the degree of injury to the bone completely precludes restoration of a smooth joint surface. A short account is given of injuries to the knee ligaments and cartilages, but the reader has to turn to the author's book on orthopaedics for an account of loose bodies in the joint and chondromalacia patellae. Perhaps it would be better in a later edition to describe these clinically very similar conditions all in one chapter.

The information given is reliable and should not lead the examination candidate into trouble. The book will be useful, not only to student and general practitioner, but also to casualty officers, ship's doctors and industrial health officers, who occasionally have care of the early treatment of fractures. It can also serve as a sound basis for the reading of those up for higher surgical examinations.

This excellent little book may be strongly recommended, especially to the undergraduate student.

A.J.H.

\section{AN OUTLINE OF BACTERIOLOGY AND IMMUNITY}

By Ronald Hare, M.D. Pp. ix $+4 \mathrm{r} 8$, illustrated. London: Longmans, Green and Co. 1956. 35 s.

The present generation of Medical Students has been less well served than its predecessors in the matter of new text books and although, since the war there have been a number of monographs dealing with special aspects of the subject, few new names have appeared among the authors of standard books in Bacteriology.

Professor Hare's book must, therefore, be welcomed as an attempt to present the subject briefly for the Medical Student. This book is not designed for the postgraduate microbiologist and does not set out to replace any reference book. Anyone reviewing it will inevitably feel that his several special interests have been inadequately emphasized, but while we have such a reference book as 'Topley and Wilson' further expansion in a book to be read is probably undesirable.

The form of the work retains something of its origin as a series of lectures and, like the recent books by Professor Payling-Wright and Sir Howard Florey, its purpose is to emphasize those aspects of the subject which cannot be left out of the under- 
graduate's curriculum. Certainly the London Medical Student will find that the emphasis on applied and diagnostic bacteriology is also that of the examiners in the subject, and it will find support from the other teachers in the universities. Professor Hare's own experiences in epidemiology and virus diseases, no less than in bacteriology, prevent the book from being narrow and unbalanced.

It is good to find that the fungus infections have been placed in close proximity to actino-mycosis: a position which will appeal to the student and possibly persuade him not to regard them as something isolated and difficult. The success or failure of the book will probably depend on whether the students find it readable as well as informative.

The references, usually about three to a page are interesting in including original publications and modern reviews next to each other, so that we find 1887 and 1954 in close juxtaposition. The students working for a Pass Degree would be well advised to look at this book.

W.H.H.

\section{PEPTIC ULCER}

\section{Diagnosis and Treatment}

By Clifford J. Barborka, M.D., M.S., D.Sc., F.A.C.P. and E. Clinton Texter, JR., M.D. Pp. xiii +290 , with 33 illustrations. London: J. \& A. Churchill Ltd. 1955. 50s.

This is an up-to-date American account of modern ideas on the management of this exceedingly common complaint. The style tends to be verbose, but not to the extent of obscuring the authors' meaning.

The thorny question of the mechanism of pain production in ulcer is fairly presented and a synthesis of the conflicting theories is attempted. However, in the reviewer's opinion, the chasm separating the two main parties is far wider and deeper than the authors imagine.

Anticholinergic drugs, of the banthine series, receive a whole chapter to themselves. Enthusiasm for these drugs has been cooler in this country than in the United States but, as the authors point out, they are valuable in relieving severe pain during uncomplicated exacerbations.

The 'psychosomatic' aspect of peptic ulcer is moderately and sensibly treated. The authors' attitude may be summed up by their statement that ' good, informal psychotherapy can be carried out by the practitioner who is possessed of common sense.' This attribute would be valuable in many fields of psychosomatic medicine.

Two omissions seem serious. Firstly, in a text of this size and detail some mention should have been made of peptic ulceration in association with hiatus hernia. Secondly, in the treatment of pyloric stenosis nothing is said of the pathology and treatment of the profound electrolyte disturbances which follow prolonged vomiting, and their serious effect on kidney function. Even if surgery is required for relief of the obstruction, it should be a point of honour for the physician to present his patient to the surgeon in a fit state for operation.

Gastric ulcer receives a separate chapter, but even so the reviewer feels that more stress should have been laid on the differences between gastric and duodenal ulcer. Though the management in many cases is similar in the two diseases, evidence is accumulating that they are of totally different aetiology.

P.H.S.

\section{A TEXTBOOK OF SURGICAL PATHOLOGY}

By C. F. W. Illingworth, C.B.E., M.D., Ch.M., F.R.C.S., and B. M. Dick, M.B., F.R.C.S. Seventh Edition. Pp. viii +730 , with 322 illustrations. London: J. \& A. Churchill Ltd. 1956. 63s.

Like the other books with which Professor Illingworth is connected, this has a clarity of style and a commonsense outlook which will be welcomed by all readers, and particularly by the overburdened Final Fellowship candidate.

In general it has been brought well up to date in this edition, and it is a reliable and comprehensive guide to surgical pathology. A very few sections, such as those on hydronephrosis and stricture of the ureter, require re-writing because they are obscure, and in one or two places, such as the account of melanomata, important work has been omitted.

Apart from a few such instances the book is a first-class production, with good illustrations and helpful references. It can be thoroughly recommended.

H.L.B.

\section{THE CHRISTCHURCH HOSPITAL MEDICAL MANUAL}

Edited by C. T. Hand Newton, D.S.O., M.D., F.R.A.C.P., F.R.C.S. Fourth edition. Pp. I73. Christchurch: N. M. Peryer Ltd. 1956. New Zealand. Price 27 s.

The scope of this book can only be described as ' parochial.' Most of the matter in it is of interest only to those working in the Christchurch Hospital (N.Z.), including such details as how to make an appointment wih the X-ray department (ring the appointment clerk, extension No. 792). Of the remaining material, there are sections dealing with the various laboratory investigations and their interpretation; this ground is better covered in many standard works on the subject. There is, however, a thoughtful little section on electrolyte balance which many house officers would find helpful. The price seems excessive for anyone who does not need a guide to Christchurch Hospital. 